American Journal of Applied Sciences 7 (7): 954-961, 2010

ISSN 1546-9239

(C) 2010 Science Publications

\title{
Influence of Oil Contamination on Geotechnical Properties of Basaltic Residual Soil
}

\author{
Zulfahmi Ali Rahman, Umar Hamzah, Mohd. Raihan Taha, \\ Norsheila Sofhia Ithnain and Noorulakma Ahmad \\ Environmental Science Program, School of Environmental and Natural Resource Sciences, \\ Faculty of Science and Technology, University Kebangsaan Malaysia (43600) Bangi Selangor, Malaysia
}

\begin{abstract}
Problem statement: Oil contamination due to accidental spillage or leakage brings hefty damage to the environments. It percolates steadily into subsurface environments and contaminates the soil and water system. Hydrocarbon contamination has not just affected the quality of the soil but will also alter the physical properties of oil-contaminated soil. Approach: This study presented the geotechnical properties of oil-contaminated soils as well as uncontaminated soils for comparison. Testing programs performed on the studied soils included basic properties, Atterberg limit, compaction, permeability and unconsolidated undrained triaxial tests. The base soils used were originated from weathered basaltic rock of grades V and VI. Soil samples were artificially contaminated with 4, 8, 12 and $16 \%$ oil of the dry weight of based soils. Results: The results showed that the oil contamination decreased the liquid limit and plastic limit values for both grades of weathered soils. For soil grade V, the decrease in plastic limit and liquid limit were represented by 21 and 39\%, respectively. Meanwhile, for soil grade VI, the drop was significantly high for liquid limit (39\%) and lower for plastic limit (19\%) if compared to soil grade V. The oil-contaminated soils also indicated a lower Maximum Dry Density (MDD) and optimum water content if compared with uncontaminated soils. The MDD for soil grade V and VI decreased from 1.67-1.50 and 1.60-1.55 g cm respectively. The OMD values dropped from $23.5-17.5 \%$ for soil grade $\mathrm{V}$ and $23.0-16.5 \%$ for soil grade VI when oil contents were increased. A reduction in permeability was observed as a result of the oil contamination. The permeability of soil grade V and VI decreased from 3.74-0.22 and $2.65-0.22 \mathrm{~cm} \mathrm{sec}^{-1}$, respectively. In terms of undrained shear strength, $\mathrm{C}_{\mathrm{u}}$ was clearly affected by the increase in oil content in contaminated soils. Both soil grades showed stress dependant behavior with a brittle mode of failure. The $\mathrm{C}_{\mathrm{u}}$ values for uncontaminated soils of both grades were 126 and $106 \mathrm{kPa}$ and then dropped to very close values of 35 and $32 \mathrm{kPa}$ at oil content of $16 \%$. Conclusion: The results showed that the addition of oil has adverse effects to the geotechnical properties of the studied residual soil. Contaminated residual soils might be used for geotechnical purposes and these results will benefit to engineers or decision makers in recycling or re-using of contaminated soils.
\end{abstract}

Key words: Oil-contaminated soil, basaltic soil, compaction, undrained strength

\section{INTRODUCTION}

Accidental oil spillage or leaking has caused severe damage to the environment. Oil contamination can adversely affect the soil microbes and plant as well as contaminate groundwater resources for drinking or agriculture (Hong et al., 2005). Hydrocarbon itself can separate into solid, liquid and gaseous phases which either remain closely to the leaking places or migrate within the groundwater system or absorbed on grains as an immobile residual fluids. The properties of soils and migration substances control the rate of migration, changes of composition and properties of migration substance. In addition, hydrocarbon contains undissolved components of Dense Non-Aqueous Phase Liquid (DNAPL) and Light Non-Aqueous Phase Liquid (LNAPL) which can travel vertically or horizontally in long distances under gravitational influence which require different treatment depending on the nature and extent of contamination (Zogala et al., 2009). Cleaning of oil-contaminated soil commonly depends on excavating the material followed by subsequent

Corresponding Author: Zulfahmi Ali Rahman, Environmental Science Program,

School of Environmental and Natural Resource Sciences, Faculty of Science and Technology, University Kebangsaan Malaysia (43600) Bangi Selangor, Malaysia

Tel: +603 89213318 Fax: +603 892533578 
treatment, incinerator or disposal in landfill. This usually involves a complicated task especially located under storage facilities by virtue of high cost and limited disposal facilities of excavated soil (Shah et al., 2003).

The hydrocarbon contamination will not just affect the quality of the soil but will also alter the physical properties of oil-contaminated soil. This will lead to geotechnical problems related to construction or foundation structure on this oil-contaminated site. Most associated impacts of oil contaminant are excessive settlement of tanks and breakage of pipeline (Mackenzie, 1970). The effect of temperature on strength, permeability and compaction was studied by Aiban (1998). The utilization of highly weathered soil for road base led to causes of damage from rainwater erosion and traffic (Millogo et al., 2008). Attempt has been made to use oil-contaminated sand in asphalt concrete for secondary road material (Al-Mutairi and Eid, 1997). A number of related studies were carried out in order to investigate the geotechnical behavior oilcontaminated soil (Evgin and Das, 1992; Al-Sanad and Eid, 1995; Al-Sanad and Ismail, 1997; Puri et al., 1994; Shin et al., 1999; Shin and Das, 2001; Khamehchiyan et al., 2007). Jamrah et al. (2007) investigated the geotechnical properties of untreated contaminated soils of Oman and comparison had been made with the treated soils.

A microscopic study on oil-contaminated clay was also presented by Habib-ur-Rahman et al. (2007) in order to understand the fabric and interaction between oil and clay mineral under Scanning Electron Microscope (SEM). Meegoda and Ratnaweera (1994) studied the compressibility behavior of contaminated fine-grained soils of low plasticity and high plasticity clays ( $\mathrm{CL}$ and $\mathrm{CH}$ ). The results showed that compressibility is controlled by the mechanical and physicochemical factors. The purpose of this study is to present some of studied geotechnical properties of oilcontaminated soil originated from weathered basaltic rock of grade V and VI, in terms of consistency limits, compaction effort, permeability tests and soil shear strength. The geotechnical properties of contaminated soil were made a reference to uncontaminated soil. It is also vital to understand the behavior of oil-contaminated soil since many of this weathered earth material is widely being used in many geotechnical works e.g., landfill liner, embankment, base material and backfill.

\section{MATERIALS AND METHODS}

Background of the study area: For the purpose of preparing the oil-contaminated samples, base soils from highly and completely weathered basaltic rock was selected. The sampling site is located in Kuantan Pahang of Peninsular Malaysia (Fig. 1). Geologically, the basaltic magma flowed out through dolerite dyke and overlain the granitic bodies of Mesozoic age at north and southwest of Kuantan (Bignell and Snelling, 1977). Basaltic rocks of quaternary age are largely found in this area. The basaltic rocks have experienced drastic weathering which change its physical appearance into dark reddish brown (2.5YR3/4) color due to high iron content. The soil posses friable and porous in dry state but become sticky and plastic as it is a typical characteristic of clayey soil. Developments of petroleum-related infrastructures e.g., fuel storages, underground pipelines and petrochemical facilities have extended to areas which are dominated by this weathered basaltic rock.

Sample preparation and experimental program: Base soil for preparing contaminated samples was collected from two profiles to represent the weathered basaltic soil of grade V and VI. These disturbed samples were collected using auger at $30 \mathrm{~cm}$ below the ground surface. Disturbed samples were stored airtight plastic containers before being air dried at room temperature for $72 \mathrm{~h}$. Seven uncontaminated soils were initially analyzed for index properties and classified as per unified soil classification scheme.



Fig. 1: Location of the sampling of the basaltic soil in study area 
Am. J. Applied Sci., 7 (7): 954-961, 2010

The uncontaminated soil characteristic variables were particle size distribution, clay minerals, specific gravity, Atterberg limits, compaction, permeability and unconfined compression strength. Dry sieving and hydrometer (size passing sieve number 200) techniques were used for particle size distribution analysis. Dominant clay minerals of the studied soils were determined using the $\mathrm{x}$-ray diffraction analysis. A Philip x-ray diffractometer equipped with Ni-filtered $\mathrm{CuK}_{\alpha}$ radiation generate at $30 \mathrm{kV}$ and $30 \mathrm{~mA}$ with a scan speed of $4^{\circ} 2 \theta \mathrm{min}^{-1}$. Prior to analysis soil have to be pulverized into powder state. Pycnometer bottle technique was adopted to determine the specific gravity of soil samples. Methods applied for particle size distribution, specific gravity, consistency limits, compaction, permeability and unconsolidated undrained strength tests for soil were referred to the British Standard Institution 1377 (1990a; 1990b; 1990c; 1990d) Part 2, 4, 5 and 7.

Further tests of the effects of hydrocarbon on geotechnical properties were carried out on contaminated soils (four samples). The tests would involve Atterberg limits, compaction, permeability and undrained tests. Contaminated soil was divided into a number of sets. Each set contained different level of hydrocarbon contamination namely $2,4,8,12$ and $16 \%$ of dried weight. In this study, engine oil specified for 2stroke engine that is available in market was used to represent hydrocarbon contamination in soil samples. The engine oil had the following properties: Density (at $\left.15^{\circ} \mathrm{C}\right)=0.889 \mathrm{~kg} \mathrm{~L}^{-1}$, pour point $=-6^{\circ} \mathrm{C}$, flash point $=$ $266^{\circ} \mathrm{C}$, kinematic viscosity $\left(\right.$ at $\left.40^{\circ} \mathrm{C}\right)=98.2 \mathrm{cSt}$ and kinematic viscosity $\left(\right.$ at $\left.100^{\circ} \mathrm{C}\right)=11.1 \mathrm{cSt}$. Oil engine was thoroughly mixed with soil and the mixture was permitted to cure in closed container at ambient temperature for fourteen days. After curing period, the Atterberg limits and permeability of contaminated soils were determined at different contents of added oil. Compaction characteristic tests were performed using $2.5 \mathrm{~kg}$ standard proctor while permeability tests of contaminated soils adopted a falling head permeameter method. For unconsolidated undrained tests, three contaminated soils were evaluated for each percentage of added hydrocarbons in order to establish the undrained soil strength. Therefore, a total of twelve contaminated soils and three uncontaminated soils were generated from the compaction mould in order to perform unconsolidated undrained triaxial tests at Maximum Dry Density (MDD) and Optimum Moisture Content (OMC). This would be carried in conventional compression unconsolidated undrained triaxial tests. All soil samples were sheared at constant

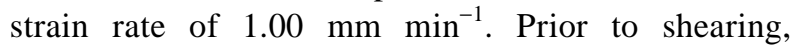

samples were pressurized under confining cell pressures, $\sigma_{3}$ of 140,280 and $420 \mathrm{kPa}$.

\section{RESULTS AND DISCUSSION}

Uncontaminated soil properties: The soils from the weathered basaltic rock of grade V and VI are of sandy loam and silty loam textures, respectively. The particle size distribution curves of both soil grades are shown in Fig. 2. Results from the XRD analysis indicated the presence of quartz, feldspar and clay minerals of kaolinite with minor amount of gibbsite and goethite in both soils. Illite mineral was detected in soil of grade $\mathrm{V}$ (Table 1). Kaolinite and illite can be alteration products from chemical weathering of feldspar. Gibbsite is an important ore of aluminum and aluminum hydroxide is one of its mineral forms. Meanwhile goethite is usually formed from weathering of iron-rich minerals or alteration of kaolinite mineral. The specific gravity for the basaltic soils ranged between 2.64 and 2.91 (Table 1). The high value of specific gravity may have been influenced mainly by the presence of goethite mineral as this supported by the XRD analysis.

Table 1: The soil characteristics of uncontaminated soil of weathered basaltic rock

\begin{tabular}{lll}
\hline Properties of soil & Grade V & Grade VI \\
\hline Particle size distribution (\%) & & \\
Sand & 50 & 39 \\
Silt & 47 & 58 \\
Clay & 2 & 3 \\
XRD analysis & Kaolinite, gibbsite, & Kaolinite, gibbsite, \\
& goethite, illite & goethite \\
Mean specific gravity & 2.64 & 2.91 \\
Atterberg limits $(\%)$ & & \\
Liquid limit, $\mathrm{w}_{\mathrm{L}}$ & 62 & 66 \\
Plastic limit, $\mathrm{w}_{\mathrm{p}}$ & 41 & 35 \\
Plasticity index, $\mathrm{I}_{\mathrm{p}}$ & 21 & 31 \\
Compaction characteristics & & \\
MDD (g cm ${ }^{-3}$ ) & 1.67 & 1.60 \\
OWC $(\%)$ & 24.5 & 23.5 \\
Permeability $\left(\mathrm{k}, \mathrm{cm} \mathrm{sec}^{-1}\right)$ & $3.74 \times 10^{-5}$ & $2.65 \times 10^{-5}$ \\
$\mathrm{C}_{\mathrm{u}}, \mathrm{kPa}$ & 126 & 106 \\
\hline XRD: X-Ray Diffraction; & $\mathrm{MDD}: \mathrm{Maximum}^{-5}$ &
\end{tabular}

XRD: X-Ray Diffraction; MDD: Maximum Dry Density; OMD: Optimum Moisture content; $\mathrm{c}_{\mathrm{u}}$ : Undrained strength

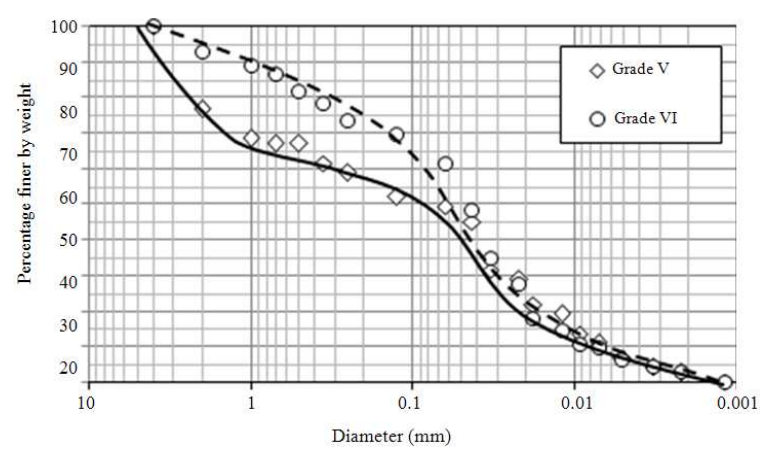

Fig. 2: Particle size distribution curves of the studied soils 
Am. J. Applied Sci., 7 (7): 954-961, 2010

Table 2: Variation of Atterberg limit values of contaminated soils for weathered basaltic rock of grades V and VI

\begin{tabular}{|c|c|c|c|c|c|c|}
\hline Oil content, $(\%)$ & $\begin{array}{l}\text { Liquid } \\
\text { limit, } \mathrm{w}_{\mathrm{L}}(\%)\end{array}$ & $\operatorname{Diffr}^{\Psi}(\%)$ & $\begin{array}{l}\text { Plastic } \\
\text { limit, } \mathrm{w}_{\mathrm{p}}(\%)\end{array}$ & Diffr. $^{\Psi}(\%)$ & $\begin{array}{l}\text { Plastic } \\
\text { index, } \mathrm{I}_{\mathrm{p}}(\%)\end{array}$ & Diffr. $^{\Psi}(\%)$ \\
\hline \multicolumn{7}{|l|}{ Soil grade $V$} \\
\hline 0 & 62.1 & \multirow{5}{*}{21.0} & 42.0 & \multirow{5}{*}{39.0} & 20.1 & \multirow{5}{*}{17} \\
\hline 4 & 58.5 & & 38.4 & & 20.1 & \\
\hline 8 & 56.2 & & 35.0 & & 21.2 & \\
\hline 12 & 52.3 & & 30.0 & & 22.3 & \\
\hline 16 & 49.1 & & 25.5 & & 23.6 & \\
\hline \multicolumn{7}{|l|}{ Soil grade VI } \\
\hline 0 & 66.0 & \multirow{5}{*}{39.0} & 35.0 & \multirow{5}{*}{19.0} & 31.0 & \multirow{5}{*}{19} \\
\hline 4 & 56.1 & & 32.0 & & 24.1 & \\
\hline 8 & 49.1 & & 31.8 & & 17.3 & \\
\hline 12 & 44.2 & & 30.4 & & 13.8 & \\
\hline 16 & 40.0 & & 28.2 & & 11.8 & \\
\hline
\end{tabular}

${ }^{\Psi}$ Diffr: Value of $\mathrm{w}_{\mathrm{L}}$ or $\mathrm{w}_{\mathrm{p}}$ or $\mathrm{I}_{\mathrm{p}}$ at $(0-16 \%)$

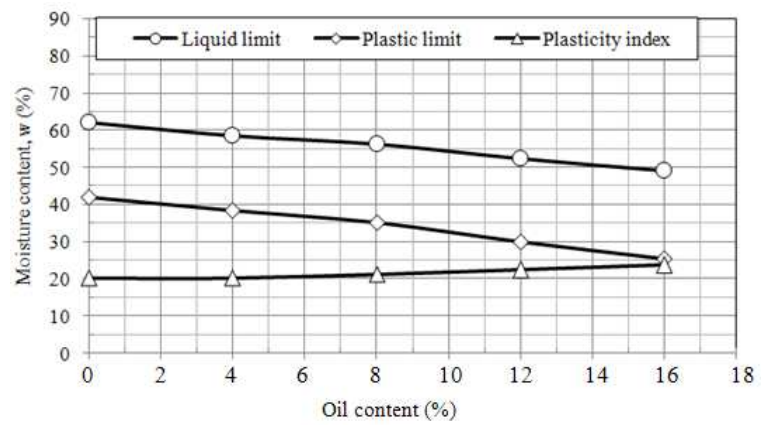

(a)

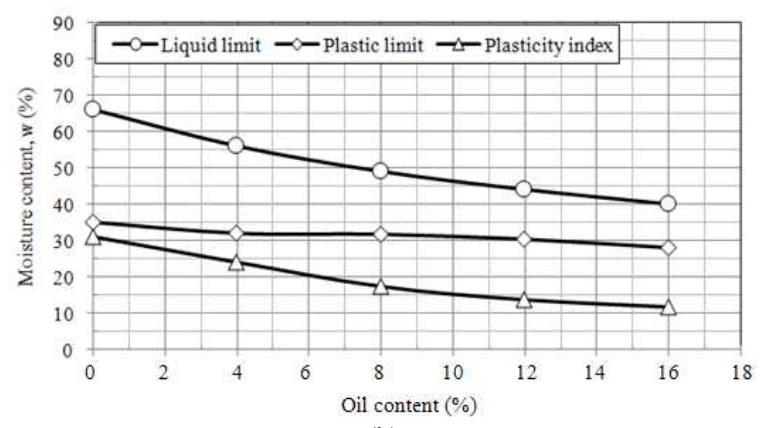

(b)

Fig. 3: The results of the Atterberg limit values for basaltic soils for (a) grade V (b) grade VI

The average values of liquid limits for uncontaminated soils are $62 \%$ for grade $\mathrm{V}$ and $66 \%$ for grade VI, respectively. For the liquid limit, uncontaminated soils of grade V and VI gave average values of 41 and 35\%, respectively. From the liquid and plastic limits results, the plasticity index, PI for uncontaminated soil of grade $\mathrm{V}$ was $21 \%$ while grade VI gave PI value of $31 \%$. The plotting of the fines on the Casagrande plasticity chart classified the soils as $\mathrm{MH}$ and MV materials (below a line) under the unified soil classification system.
Compaction tests performed on uncontaminated soils were to establish the Maximum Dry Density (MDD) and Optimum Water Content (OWC) of both soils. The results indicated that both soils have quite close values of MDD and OWC as shown in Table 1. Permeability tests of uncontaminated soil of grade $\mathrm{V}$ and VI gave $3.74 \times 10^{-5}$ and $2.65 \times 10^{-5} \mathrm{~cm} \mathrm{sec}^{-1}$, respectively. The results of unconsolidated undrained triaxial tests were performed on uncontaminated soils are shown in Table 1. The undrained soil strength of the uncontaminated samples ranged from 106-126 kPa.

Geotechnical properties of contaminated soils: The effect of hydrocarbon contamination has clearly seen on the geotechnical properties of the studied soils. The Atterberg limits consists of plastic limit and liquid limit are the state at correspond to soil behavior as wetting condition change. The results of the liquid limit $\left(\mathrm{w}_{\mathrm{L}}\right)$, plastic limit $\left(\mathrm{w}_{\mathrm{p}}\right)$ and plasticity index $\left(\mathrm{I}_{\mathrm{p}}\right)$ on the contaminated soils of grades $\mathrm{V}$ and VI are summarized in Table 2 and graphically presented in Fig. $3 a$ and $3 b$. It is clearly seen from Fig $3 a$ and $3 b$ that both liquid limit and plastic limit decreased with the increase in oil contents. The decreases in the liquid limits for the contaminated soil of grade V and VI were represented by 16 and 38\%, respectively. However the plastic limit for the contaminated grade VI soils has indicated a slight change (20\%) in moisture content with the increase of oil contents if compared with the contaminated soil of grade V $(38 \%)$. Plastic index increased with the addition of oil for contaminated soils of grade V. In other hand the plastic index decreased with increase in oil for contaminated soil of grade VI due to slightly drop in plastic limits. Generally, the presence of oil has decreased the moisture contents of the liquid and plastic limits of the contaminated soils. The explanation for this condition is the presence of water around the charged clay particles lessen as nonpolarised liquid of oil occupies the soil. Oil would make 
earlier contact with clay particles, causing a removal of interaction between water and clay particles. Water acts as binding agent between clay particles that contributes to the plasticity characteristic. Khamehchiyan et al. (2007) observed a similar behavior for SM and CL soils. Meanwhile Shah et al. (2003) showed that the contaminated soils increased the liquid and plastic limits and decreased the plastic index as compared to uncontaminated CL soils.

The results from the compaction tests performed from the British Standard compactive effort $(2.5 \mathrm{~kg})$ are shown in Table 3. The compaction characteristics were also presented in graphical plots as shown in Fig. 4a and $4 \mathrm{~b}$. The compaction curves for contaminated soils clearly moved to the left the uncontaminated soils' curve as oil content increased. The affect of oil contamination on the maximum dry density and optimum moisture content can be seen from Fig. 5a. The maximum dry density values for contaminated soil of grade $\mathrm{V}$ showed a drastic drop from $1.67-1.57 \mathrm{~g} \mathrm{~m}^{-3}$ when $4 \%$ oil content was added to soil, then the drop continued linearly from $8-16 \%$ oil contamination. Contaminated soil of grade VI showed a steady drop in maximum dry density as oil content increased, but the drop was slightly smaller than the contaminated soil from grade $\mathrm{V}$. These results are consistent with the results presented by other workers who studied a similar oil-contaminated material (Khamehchiyan et al., 2007; Shah et al., 2003). Al-Sanad and Eid (1995); Meegoda et al. (1998) and Bignell and Snelling (1977) found that the maximum dry density for SW soils increased as oil content increased up to a particular values, then followed by decreasing trend beyond that particular oil percentage. Fig. 5b shows the relationship between the moisture content and oil content from which it clearly indicated that drawdown trend of optimum moisture content with the increase in oil content.

Table 3: Compaction test results of contaminated soils for weathered

\begin{tabular}{lll}
\multicolumn{2}{c}{ basaltic rock of grades V and VI } \\
\hline & $\begin{array}{l}\text { Maximum } \\
\text { dry density } \\
\text { MDD }\left(\mathrm{g} \mathrm{cm}^{-3}\right)\end{array}$ & $\begin{array}{l}\text { Optimum } \\
\text { moisture content } \\
\text { OMC }(\%)\end{array}$ \\
Oil content $(\%)$ & & \\
\hline Soil grade V & 1.67 & 23.5 \\
0 & 1.57 & 21.4 \\
4 & 1.55 & 20.0 \\
8 & 1.53 & 18.5 \\
12 & 1.50 & 17.5 \\
16 & & \\
Soil grade VI & 1.60 & 23.0 \\
0 & 1.58 & 22.5 \\
4 & 1.56 & 22.0 \\
8 & 1.55 & 20.0 \\
12 & 1.55 & 16.5 \\
16 & & \\
\hline
\end{tabular}

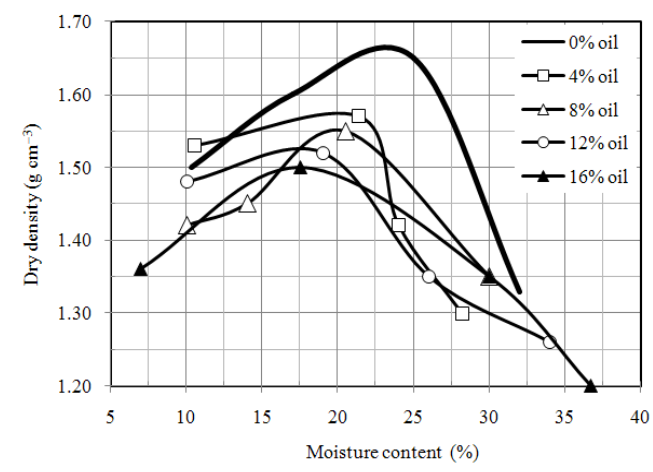

(a)

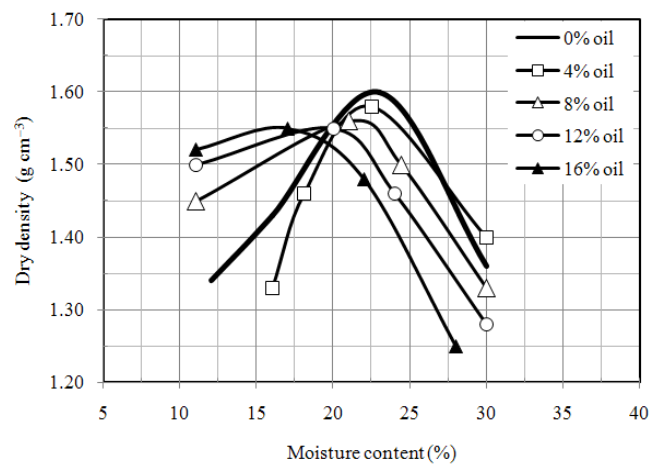

(b)

Fig. 4: Compaction curves for basaltic soils of (a) grade $\mathrm{V}$ and (b) grade VI

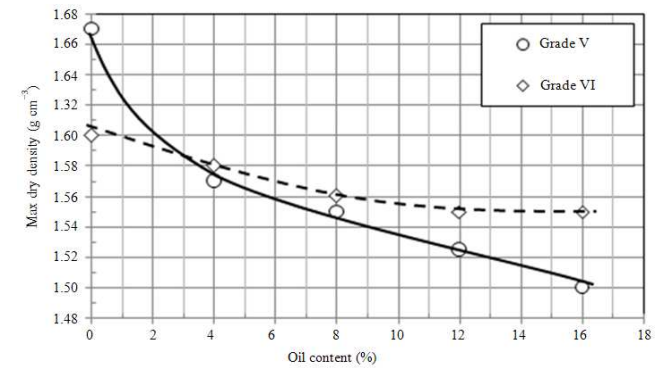

(a)

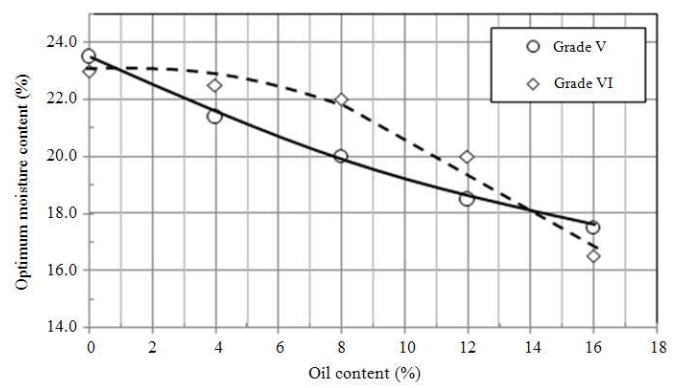

(b)

Fig. 5: (a) Max dry density-oil content curves (b) moisture content-oil content for basaltic soils of grade V and VI 
It clearly suggests that the moisture content required to achieve maximum dry density has decreased when oil content increased in contaminated soil. This is probably due to the fact that oil has partially occupied the inter-particles spaces and the occurrence of oil has changed the soil to a state of looser material than an uncontaminated soil.

The soil permeability was investigated in order to establish the capacity of soil to permit the water flow within the soil media. The permeability of basaltic soil is generally low due to high percentage of finer particles and a small void ratio. Basaltic soil contains a high fraction of sand and silt, in which silt occupies interparticles space of sands that can reduce its permeability. As expected that the permeability of both soils were reduced as oil content increased (Fig. 6). The decrease in permeability of the contaminated soils has likely associated with the clogging of some inter-particles spaces by oil. Therefore, an increase in oil content in contaminated soil will reduce the available inter-particles spaces for water seepage. The results also showed that the permeability for the uncontaminated soil of grade $\mathrm{V}$ has a higher value than soil of grade VI (Fig. 6).

Table 4: The maximum deviatoric stresses $\left(\mathrm{q}_{\max }\right)$ and applied confining stresses $\left(\sigma_{3}\right)$ for the uncontaminated and contaminated soils

\begin{tabular}{|c|c|c|c|c|}
\hline \multirow{2}{*}{$\begin{array}{l}\text { Confining } \\
\text { stress, } \\
\sigma_{3}(\mathrm{kPa}) \\
\end{array}$} & \multirow{2}{*}{$\begin{array}{l}\text { Oil } \\
\text { content, } \\
(\%)\end{array}$} & \multicolumn{3}{|c|}{ Maximum deviatoric stress, $\mathrm{q}_{\max } \mathrm{kPa}$ ) } \\
\hline & & 140 & 280 & 420 \\
\hline \multicolumn{5}{|c|}{ Soil grade $\mathbf{V}$} \\
\hline & 0 & 159 & 254 & 345 \\
\hline & 4 & 99 & 120 & 149 \\
\hline & 8 & 97 & 99 & 105 \\
\hline & 12 & 77 & 80 & 96 \\
\hline & 16 & 50 & 74 & 89 \\
\hline \multicolumn{5}{|c|}{ Soil grade VI } \\
\hline & 0 & 194 & 200 & 244 \\
\hline & 4 & 95 & 101 & 129 \\
\hline & 8 & 88 & 100 & 120 \\
\hline & 12 & 84 & 90 & 110 \\
\hline & 16 & 38 & 47 & 97 \\
\hline
\end{tabular}

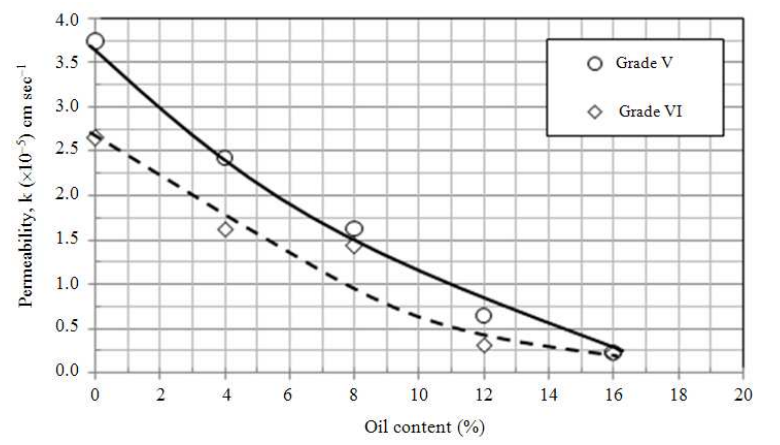

Fig. 6: Permeability curves for the basaltic soils of grade $\mathrm{V}$ and $\mathrm{VI}$
This can be explained from the soil texture of grade $\mathrm{V}$ which is dominated by sand fraction (50\%) while soil of grade VI contains sand and silt fractions of 39 and 58\%, respectively (Table 1). It can be expected here that the permeability of both soils would not change further if the oil contamination level is increased; however there is no any data to support that assumption.

The unconsolidated undrained tests were also performed on contaminated soils at different oil contents. The effect of oil contamination then was examined from the undrained strength, $\mathrm{C}_{\mathrm{u}}$ extracted from Mohr circles (assuming that friction angle, $\phi_{\mathrm{u}}=0$ ) (Craig, 1995). The results of the undrained tests at different applied confining stresses, $\sigma_{3}$ and oil content were shown in Table 4. The stress-strain curves for the tests were shown in Fig. 7 and 8, representing soils of grades V and VI, respectively.

Based on the stress-strain plots, all samples showed a drastic linear increase in deviatoric stress, $q$ up to axial strain between 1-2\% (Fig. 7 and 8). Then q increases at lower increment up to peak value before the samples collapsed. The soil samples from both grades showed stress-dependant behavior with brittle type of failure. It indicated that the maximum deviatoric stress, $\mathrm{q}_{\max }$ of oil-contaminated soils was lower than that of uncontaminated soils (Table 4).

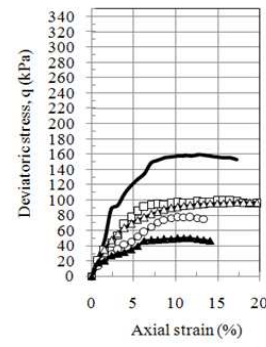

(a)

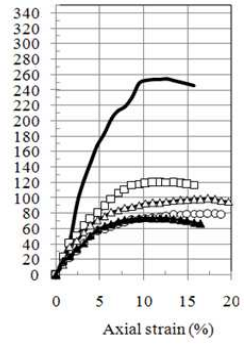

(b)

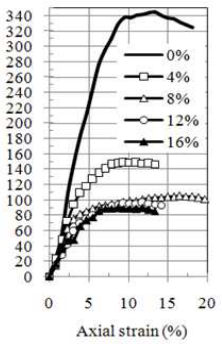

(c)
Fig. 7: Stress-strain curves for soil grade of $\mathrm{V}$ at different applied confining stress, $\sigma_{3}$ of (a) $140 \mathrm{kPa}$; (b) $280 \mathrm{kPa}$; (c) $420 \mathrm{kPa}$

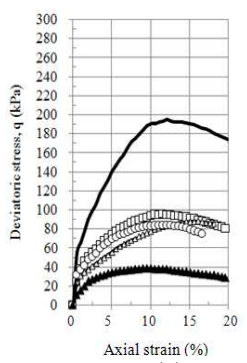

(a)

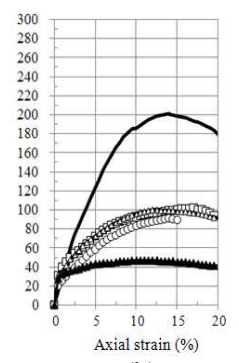

(b)

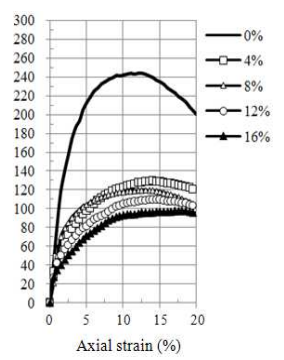

(c)
Fig. 8: Stress-strain curves for soil grade of VI at different applied confining stress, $\sigma_{3}$ of (a) $140 \mathrm{kPa}$; (b) $280 \mathrm{kPa}$; (c) $420 \mathrm{kPa}$ 


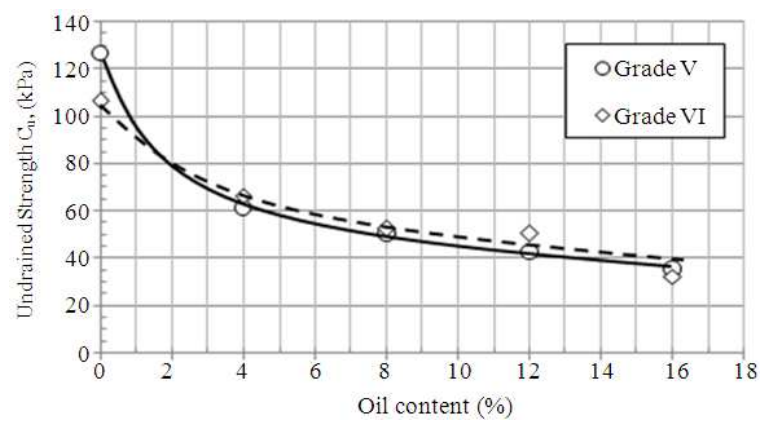

Fig. 9: Relationship between $C_{u}$ and oil contamination for both soil grades of V and VI

The effect of oil contamination on both soil grades is shown in Fig. 9. The untrained strength, $C_{u}$ for both soil grades significantly dropped from $0-4 \%$ of oil contents. Further increases in oil content to the contaminated soils indicated that a smaller change in shear strength, $\mathrm{C}_{\mathrm{u}}$. This can be described that the presence of oil with has higher viscosity than water might blanket the soil particles. By increasing the amount of oil content in particular soil, the chance of inter-particle slippage will also increase, subsequently decrease the shear strength of the soil (Rahman et al., 2010). It can be suggested that the higher the oil contamination the lower the $\mathrm{C}_{\mathrm{u}}$ value. A similar picture was also observed by Rahman et al. (2010); Habib-urRahman et al. (2007) and Shah et al. (2003) also found that the fuel oil contaminated soils gave a lower unconfined compressive strength $(37.27 \mathrm{kPa})$ than that of uncontaminated soils $(56.88 \mathrm{kPa})$.

\section{CONCLUSION}

In this study, the effects of oil contamination on some geotechnical properties are clearly observed on weathered basaltic soils. The Atterberg limits of contaminated soils were lower than that of uncontaminated soils. The maximum dry density and optimum moisture content also dropped due to increase in oil content in contaminated soils. Similar behavior was also observed on permeability and shear strength of weathered basaltic soils. A significant drop in untrained strength, $\mathrm{C}_{\mathrm{u}}$ was seen in weathered basaltic soils from $0-4 \%$ of oil content. The $\mathrm{C}_{\mathrm{u}}$ values decreased slightly with a further addition of oil content beyond $4 \%$ of oil content in contaminated soils. The role of oil is quite similar to water, it increases a chance to inter-particle slippage, thus reduce the shear strength of the contaminated soils. The results clearly showed that the oil contamination on soil system has influenced the geotechnical properties of the basaltic residual soil.
Contaminated residual soils might be used for geotechnical purposes and these results will benefit to engineers or decision makers in recycling or re-using of contaminated soils.

\section{ACKNOWLEDGEMENT}

We thank the Ministry Of Sciences, Technology and Innovation (MOSTI) on the support of this research project under research grant 060102SF0276. Special thank also due to laboratory staffs at School of Environmental and Natural Resource Sciences, Faculty of Science and Technology, UKM for the assistance of sample preparation and soil testing.

\section{REFERENCES}

Aiban, A., 1998. The effect of temperature on the engineering properties of oil-contaminated sand. J. Environ. Int., 24: 153-161. DOI: 10.1016/S01604120(97)00131-1

Al-Mutairi, N.A. and W.K. Eid, 1997. Utilization of oil-contaminated sands in asphalt concrete for secondary roads. Mater. Struct., 30: 497-505. DOI: 10.1007/BF02524778

Al-Sanad, H.A. and N.F. Ismail, 1997. Aging effect on oil-contaminated Kuwait sand. J. Geotech. Geoenviron. Eng. ASCE, 123: 290-294. DOI: 10.1061/(ASCE)1090-0241(1997)123:3(290)

Al-Sanad, H.A. and W.K. Eid, 1995. Geotechnical properties of oil-contaminated Kuwait sand. J. Geotech. Eng., ASCE, 121: 407-412. DOI: 10.1061/(ASCE)-(1995)121:5(407)

Bignell, J.D. and N.J. Snelling, 1977. Geochronology of Malayan granites. Overseas Geol. Miner. Resour., 47: 111.

British Standard Institution 1377, 1990a. Methods of Test for Soil for Civil Engineering Purposes-Part 2: Classification Tests. BS1377, London, ISBN: 0580178676, pp: 68.

British Standard Institution1377, 1990b. Methods of Test for Soil for Civil Engineering Purposes-Part 4: Compaction-Related Tests. BS1377, London, ISBN: 0580180700, pp: 70.

British Standard Institution1377, 1990c. Methods of Test for Soil for Civil Engineering Purposes-Part 5: Compressibility, Permeability and Durability Tests. BS1377, London, ISBN: 0580180301, pp: 42.

British Standard Institution1377, 1990d. Methods of Test for Soil for Civil Engineering Purposes-Part 7: Shear Strength Tests (Total Stress). BS1377, London, ISBN: 0580182649, pp: 62.

Craig, R.F., 1995. Soil Mechanics. 5th Edn., Chapman and Hall, London, ISBN: 0-412-39590-8, pp: 427. 
Evgin, E. and B.M. Das, 1992. Mechanical behavior of an oil-contaminated sand. Proceeding of the Mediterranian Conference on Environment Geotechnology, Balkema Publishers, Rotterdam, The Netherlands, pp: 101-108.

Habib-ur-Rahman, S.N. Abduljauwad and T. Akram, 2007. Geotechnical behavior of oil-contaminated fine grained soils. Elect. J. Geol. Eng., 12. http://www.ejge.com/2007/JourTOC12A.htm

Hong, J.H., J. Kim, O.K. Choi, C. Kyung-Suk and H.W. Ryu, 2005. Characterization of a dieseldegrading bacterium, Pseudomonas aeruginosa IU5, isolated from oil-contaminated soil in Korea. World J. Microbiol. Biotechnol., 21: 381-384. DOI: $10.1007 / \mathrm{s} 11274-004-3630-1$

Jamrah, A., A. Al-Futaisi, H. Hossam and S. Al-Oraimi, 2007. Petroleum contaminated soil in Oman: Evaluation of bioremediation treatment and potential for reuse in hot asphalt mix concrete. Environ. Monitor. Assess, 124: 331-341. DOI: 10.1007/s10661-006-9230-9

Khamehchiyan, M., A. H. Charkhabi and M. Tajik, 2007. Effects of crude oil-contamination on geotechnical properties of clayey and sandy soils. Eng. Geol., 89: 220-229. DOI: 10.1016/j.enggeo.2006.10.009

Mackenzie, J.M.W., 1970. Interaction between oil drops and mineral surfaces. Soc. Min. Eng., AIME., Trans., 247: 202-208.

Meegoda, N.J. and P. Ratnaweera, 1994. Compressibility of contaminated fine grained soils. Geotech. Test. J., 17: 101-112. DOI: 10.1520/GTJ10078J

Meegoda, N.J., B. Chen, S.D. Gunasekera and P. Pederson, 1998. Compaction characteristics of contaminated soils-reuse as a road base material. Proceeding of the Geocongress: Geotechnical Special Publication, Recycled Materials in Geotechnical Applications, Boston, MA., pp: 195-209.
Millogo, Y., M. Hajjaji, R. Ouedraogo and M. Gomina, 2008. Cement-laterite gravels mixture: microstructure and strength characteristics. Constr. Build. Materials, 22: 2078-2086. DOI: 10.1016/j.conbuildmat.2007.07.019

Puri, V.K., B.M. Das, E.C. Cook and E.C. Shin, 1994. Geotechnical Properties of Crude OilContaminated Sand. ASTM Special Technical Publication, No. 1221, pp: 75-88. http://scialert.net/abstract/?doi=ajaps.2010.237.249

Rahman, Z.A., H. Umar and N. Ahmad, 2010. Geotechnical characteristics of oil-contaminated granitic and metasedimentary soils. Asian J. Applied Sci., 3: 237-249. DOI: 10.3923/ajaps/2010.237.249

Shah, S.J., A.V. Shroff, J.V. Patel, K.C. Tiwari and D. Ramakrishnan, 2003. Stabilization of fuel oil contamination soil-a case study. Geotech. Geol. Eng., 21: 415-427. DOI: 10.1023/B:GEGE.0000006052.61830.1a.

Shin, E.C. and B.M. Das, 2001. Bearing capacity of unsaturated oil-contaminated sand. Int. J. Offshore Polar Eng., 11: 220-227. http://www.isope.org/publications/journals/ijope11-3/ijope-11-3-p220-abst-TM-23-Shin.pdf

Shin, E.C., J.B. Lee and B.M. Dass, 1999. Bearing capacity of a model scale footing on crude oilcontaminated sand. Geotech. Geol. Eng., 17: 123-132. DOI: 10.1023/A:1016078420298

Zogala, B., R. Dubiel, W.M. Zuberek, M. Rusin-Zogala and M. Steininger, 2009, Geoelectrical investigation of oil-contaminated soils in former underground fuel base: Borne Sulinowo, NW Poland. Environ. Geol., 58: 1-9. DOI: 10.1007/s00254-008-1458-y 